\title{
The Challenge of Housing Regeneration in the Core Area of Akure, Nigeria
}

\author{
Abiodun Olukayode Olotuah \\ Department of Architecture, Federal University of Technology, Akure 340001, Nigeria \\ olotuah@gmail.com; aoolotuah@futa.edu.ng
}

Doi:10.5901/mjss.2016.v7n3s1p431

\section{Abstract}

Housing regeneration is of utmost concern because housing is an indispensable human need, which is however deficient in many human societies. Housing is often quantitatively and qualitatively inadequate in most countries particularly Less Developed Countries. Since housing has direct impact on the health and well-being of people, its regeneration is imperative in order to have live-able environments, healthy and productive populace, and to strengthen communities and neighbourhoods. Housing regeneration could be faced with challenges depending upon different socio-economic circumstances and cultural backgrounds of the societies. This paper takes a look at housing regeneration particularly in Akure, the capital city of Ondo State of Nigeria. The paper appraises the housing situation in the core area of Akure, Nigeria and examines certain key variables that impinge on the quality of housing and which are thus cogent in the determination of the level of housing poverty experienced therein. It concludes with the assertion that housing is generally qualitatively inadequate in Akure, Nigeria and would require momentous effort to regenerate it.

Keywords: housing, live-able, Nigeria, Ondo State, regeneration.

\section{Introduction}

Housing regeneration is a worldwide concern owing to the importance of housing to humanity.

Housing regeneration, sometimes called housing renewal, is the process of renewing and upgrading housing. Where appropriate, houses may be demolished to replace them with better quality and more modern ones that improve the environment and quality of life for residents. Sometimes housing regeneration can mean much smaller scale works carried out to improve the function of housing, health and safety of occupants. Housing is one of man's important needs and it is an essential requirement for his existence. Adequacy in housing enhances the welfare and the productivity of the individual and conversely its inadequacy threatens the very basis of man's existence. This is quite evident in the circumstances of the urban poor living in slums that are prone to all kinds of communicable diseases, social and even political unrest (Sada, 1975). The place of housing in man's life is therefore eminent, necessitating its adequate provision in quantitative and qualitative terms.

In view of the enormous importance of housing to man, it is adopted as an unquestionable right of the individual by the United Nations (UN, 1971). In this regard every citizen deserves to have access to adequate housing without any hindrance whatsoever. Nigeria is a state party to the United Nation's International Covenant on Economic, Social and Cultural Rights (ICRSCR) in which housing is a part. However, studies have shown that the quality of housing in both rural and urban centres in Nigeria is pathetic (Olotuah, 1997; Olanrewaju, 2001; FGN 2004). Many of the buildings are in a state of disrepair requiring minor or major repairs to bring them to normative and structural quality. Housing regeneration is imperative in many neighbourhoods. This paper reports a research carried out in the core area of Akure, the capital city of Ondo State Nigeria, to investigate the need for housing regeneration in the neighbourhoods.

\section{Housing Poverty and Environmental Degeneration in Nigeria}

The quality of housing and the environment is of great concern in Nigeria, as in most Less Developed Countries (LDCs). This is indicative, in part, by the state of repair of buildings in both rural and urban centres. The state of repair of buildings is a crucial determinant of the habitability of buildings, which in sum informs the level of comfort, satisfaction, security and safety of the residents (Olotuah 2001, 2006). The deterioration of the conditions of urban buildings in Nigeria is a direct consequence of the rapid rate of urbanisation it is experiencing. The rapid rate of urbanisation has resulted mainly from a high rate of rural-urban migration and the increase in the number of concentration points in the urban centres. Studies have shown that this has exacerbated the deterioration of living conditions in Nigerian urban centres and had exerted 
untold stress on existing housing stock, public goods and services and basic infrastructure (Diogu 2002). This has led to a general degradation of the environment manifesting in the growth of slum conditions in the urban centres (Mabogunje, Hardoy, \& Mistra, 1978).

In the developing world, like in Nigeria, rapid urbanisation has outpaced the ability of governments to provide adequate shelter and basic amenities for the urban poor resulting in grievous urban poverty (Lewin, 1981). The high level of poverty of most urban households places the available housing stock out of their economic reach. Many of the households resort to constructing make shift dwellings with all sorts of refuse materials on illegally occupied land (Makinwa-Adebusoye, 1988). The result is the growth of slums and squatter settlements. Slums are characterized by obsolesce resulting from the combined effects of such factors as natural ageing of buildings, lack of maintenance and neglect, wrong use of buildings, wrong development of land, poor sanitation in the disposal of sewage and solid wastes, and increasing deterioration of the natural landscape (Omole, 2000).

Despite the enormous amount of money often proposed for urban investment very limited investment is made in urban infrastructure (Salau, 1992). Nigerian urban areas are thus characterized by an increasing shortage of urban services and infrastructure and this is a peculiar feature of slum areas (Basorun, 2003). Urban services and infrastructure are only accessible to a diminishing share of the population. The existing urban services are overstrained which often lead to total collapse. A large proportion of the population does not have reasonable access to safe and ample water supply, and neither do they have the means for hygienic waste and sewage disposal. The demand for urban services in Nigeria has grown over the years but the overall quality and coverage of public services have deteriorated (Olotuah 2002).

Studies have shown an overwhelming evidence of the deplorable and pathetic housing conditions in which the vast majority of urban dwellers in Nigeria live (Wahab, Adedokun \& Onibokun 1990; Omojinmi, 2000; Olotuah and Aiyetan 2006). These show the preponderance of sub-standard and structurally unsound houses found in urban centres in Nigeria. Wahab et al (1990) have shown that only one-third of urban housing is sound (Table 1). The inadequacy of the quality of most of urban housing stems mainly from the poor physical state of the buildings. The buildings are often unsafe and insecure and do not provide adequate shelter from the elements of weather. The environment in which the buildings are located is squalid in most cases, and this generally leads to slum conditions (Igwe, 1987).

Table 1: Urban Housing Conditions in Nigeria

\begin{tabular}{|c|c|c|c|c|}
\hline Sound & Requiring minor repairs & Requiring major repairs & Dilapidated & Total \\
\hline 32.8 & 43.8 & 18.7 & 4.7 & 100 \\
\hline
\end{tabular}

Source: Wahab et al (1990)

\section{Research Methodology}

\subsection{Data gathering}

This paper reports a research on urban housing in Akure, Nigeria. The research examined the influence of key features of the urban housing question in the core area of Akure, Nigeria. The instrument of research was a questionnaire designed to gather data from the field survey conducted. The research adopted a data matrix of 44 variables by 150 cases. A sample of 150 houses was randomly selected in the study area. Twelve research assistants administered the questionnaire. The questionnaire was retrieved immediately after completion. Frequency description was the univariate analysis done.

\subsection{Results and discussion}

In the assessment of the qualitative adequacy of the buildings the following variables were investigated: House type, walling material, age of buildings, type use of toilet, type of kitchen, state of repair of the buildings, household size, number of households per building, number of persons per building, number of rooms per building, number of rooms occupied by a household, and number of persons per room.

The dominant house type in the study area was the rooming house (with face-to-face rooms) built on one or two stories. The walling materials used for the buildings were mainly mud and sandcrete cement blocks. Buildings constructed with mud walls constituted $71 \%$, sandcrete cement blocks $20 \%$, while sundried/burnt bricks were $9 \%$ (Table 
2). Cracks were common features on most of the buildings, which constituted potent risks to the occupants.

Over seventy percent (70\%) of the buildings were constructed over 20 years ago. The neighbourhood has been built up before the last two decades though there were recent developments (Table 3). These were in places where the old structures were pulled down to pave way for new houses.

Table 2: Walling materials of buildings in Akure Core Area

\begin{tabular}{|l|c|}
\hline Material & Akure Core Area \\
\hline Mud & 70.73 \\
\hline Sundried/burnt bricks & 09.2 \\
\hline Sandcrete (cement blocks) & 20.07 \\
\hline Total & 100.00 \\
\hline
\end{tabular}

Source: Author's Fieldwork, 2009

Table 3: Estimated age of buildings in Akure Core Area

\begin{tabular}{|c|c|}
\hline Estimated Age & Akure Core Area \\
\hline $1-10$ & 02.50 \\
\hline $11-20$ & 18.67 \\
\hline $21-30$ & 13.83 \\
\hline $31-50$ & 28.33 \\
\hline Above 50 & 36.67 \\
\hline Total & 100.00 \\
\hline
\end{tabular}

Source: Author's Fieldwork, 2009

Sanitary facilities were hardly available in the houses in the neighbourhood. In most of the buildings the bathrooms and toilets were located completely outside, often times at the back of the buildings. The placement and layout of most of the buildings were amorphous and disorganized. As much as $11 \%$ had no toilet facilities at all while the toilets available constituted an eyesore in the neighbourhood. Pit latrines feature most in the neighbourhood (72\%) (Table 4). The toilets were constructed with corrugated zinc sheets over dug pits with concrete floor slabs. They were, in almost all cases, in insanitary conditions, which constitute a menace to the health of the residents. The mean number of persons living in a building was 32.16 and the average number of rooms per building was 5.6, with a mean of 5.74 persons per room (Table 5). This is a clear indication of overcrowding in the buildings. Kitchens were built at the back of the buildings in most cases in the neighbourhood. The residents cook along the corridors (20\%), and some cases outside the buildings altogether (62\%). Rooms purposely designed as kitchens were few in the neighbourhood as these were available in only $15 \%$ of the buildings (Table 6). In a few instances (3\%) no kitchens were provided at all.

Table 4: Distribution of houses by type of toilets

\begin{tabular}{|c|c|}
\hline Toilet type & Akure Core Area \\
\hline Water closet & 17.67 \\
\hline Pit Latrine & 71.67 \\
\hline None & 10.66 \\
\hline Total & 100.00 \\
\hline
\end{tabular}

Source: Author's Fieldwork, 2009

Table 5: Basic household data (Arithmetic Means)

\begin{tabular}{|l|c|}
\hline Mean number of households per building & 4.8 \\
\hline Mean household size & 6.7 \\
\hline Mean number of persons per building & 32.16 \\
\hline Mean number of rooms per building & 5.6 \\
\hline
\end{tabular}




\begin{tabular}{|l|l|}
\hline Mean number of rooms occupied by a household & 1.166 \\
\hline Mean number of persons per room & 5.743 \\
\hline
\end{tabular}

Source: Author's Fieldwork, 2009

Table 6: Distribution of houses by type of kitchens

\begin{tabular}{|l|c|}
\hline Types of kitchen & Akure Core Area \\
\hline Room within the house & 15.00 \\
\hline Along the corridor & 20.00 \\
\hline Detached outside & 61.67 \\
\hline None & 03.33 \\
\hline Total & 100.00 \\
\hline
\end{tabular}

Source: Author's Fieldwork, 2009

In the neighbourhood only a dismal $3 \%$ of the houses was 'sound' which implies that $97 \%$ of them required some form of repairs of varying dimensions. Those that require major repairs constitute $42 \%$, while $55 \%$ require minor repairs to bring them to a reasonable level of normative and structural quality (Table 7). State of repair of buildings takes into consideration the soundness of the roofs, walls, floors and foundations. The soundness of roof structures implies absence of leakages of roof cover and damages to roof frame. The soundness of walls is the absence of cracks, surface wear, tearing or peeling off of surface plaster and paints; while soundness of floors refers to absence of cracks, surface wear, tearing or peeling off of floor finish. The soundness of foundations refers to the ability to withstand forces of settling and erosion.

Table 7: State of repair of buildings in Akure Core Area

\begin{tabular}{|l|c|}
\hline State of repair & Akure Core Area \\
\hline Sound & 03.33 \\
\hline Requires minor repairs & 54.67 \\
\hline Requires major repairs & 42.00 \\
\hline Dilapidated & 0.00 \\
\hline Total & 100.0 \\
\hline
\end{tabular}

Source: Author's Fieldwork, 2009

This is a lucid pointer to the fact that the magnitude of housing poverty in the neighbourhood was very high and the buildings and the neighbourhood require urgent regeneration. In assessing the quality of the housing in a neighbourhood, the perception of the residents on the question is of utmost importance. It is an important component of the livability of their environment. Over half of the residents considered the quality of their housing as below average; while almost a fifth of the residents considered it as poor (Table 8). This further confirms the imperativeness of housing regeneration in the core area of Akure, the capital city of Ondo State, Nigeria.

Table 8: Perception of residents on the quality of their housing

\begin{tabular}{|c|c|}
\hline & Akure Core Area \\
\hline Excellent & 01.67 \\
\hline Very good & 05.00 \\
\hline Good & 18.33 \\
\hline Below average & 56.67 \\
\hline Poor & 18.33 \\
\hline Total & 100.0 \\
\hline
\end{tabular}

Source: Author's Fieldwork, 2009 


\section{Challenges of Housing Regeneration in Nigeria}

\subsection{Housing shortages}

The excruciating problem of housing poverty as characterized by poor building conditions and overcrowding in existing houses is symptomatic of the high magnitude of housing needs in Nigeria. The Nigerian government and the private sector have been unable to meet the housing needs of the populace (Federal Government of Nigeria, FGN 2004). There is acute housing shortage in the country, especially in the urban centres, because the provision of housing has never really matched the population growth of the country (Adejumo, 2008; Asunmo and lyagba, 1997; Onyebueke, 2002; Isimi, 2005; Okedele, Adebayo, Iweka and Uduma-Olugu, 2009; Okupe 2002). Concomitant with this is the low economic capacity of most urban households owing to a depressed economy and unequal income distribution. The high percentage of urban dwellers living in slums in inadequate dwellings devoid of minimum structural and normative quality provides sufficient evidence of the high magnitude of housing need in Nigeria.

While a large number of dwellings need to be constructed or regenerated to meet the housing need of urban dwellers, the vast majority of the populace does not have the economic means to afford them. They cannot therefore make effective demand of housing which relates to the accommodation for which people are able and willing to pay without regard to social desiderata or personal aspirations that they cannot fulfill owing to paucity of money.

\subsection{Poverty}

Poverty is the lack of income needed to acquire the minimum necessities of life. These necessities include caloric intake (consumption item necessary for subsistence), housing, medical care and clothing. Poverty is essentially a physical matter (Galbraith, 1958). The poor are characterized by little material possessions, constant struggle for survival, low education, unstable employment or outright unemployment, low nutritional status, large families, lack of access to municipal services and poor housing conditions (Makinwa-Adebusoye, 1988; Soyombo, 1987; Baratz \& Grisby 1972; Osinubi 2003). Poverty does not only limit the ability to acquire basic amenities of life it also restricts the choice of living environment, which is why the poor are compelled to live in insanitary environment. Housing is thus a good indicator of the level of poverty.

It is a highly visible dimension of poverty and it reflects the living standards of a society and the quality of life of the people (Ozo, 1987; Ogunpola and Ojo 1975; Asiodu, 2001; Venkatarama, 2004; Adedeji \& Olotuah, 2012). Nigeria is the 6th largest producer of crude oil in the world, but in spite of this the vast majority of Nigerians are living in abject poverty (Ajanlekoko, 2001; Nwaka, 2006). Research has shown that Nigeria is one of the poorest countries in terms of human development despite its oil wealth (Ali-Akpajiak \& Pyke (2003). It is a rich country with a poor population - the poorest and most deprived in the Organisation of Petroleum Exporting Countries (OPEC). It has been estimated that 48.5 percent of the population is living below poverty line (Alagbe 2008).

\subsection{Poor social services}

Infrastructural facilities and social services constitute an essential part of housing without which a lot of strain would be imposed on the physical well-being of occupants. Their inadequacy is an indication of the inefficiency of the relevant authorities and the unfeeling attitude of government to the social welfare of its citizens, which is a determinant of their productivity (UNCHS 1994, 2002; Olotuah 2002). Improvement on the quality of public infrastructure and services is dependent on the focus and attention of government, although alternative and complimentary efforts are made by individuals as temporary or short-term measures.

\subsection{Informal housing procedures in existing housing stock}

In Nigeria housing is provided mainly by the private sector. The private sector comprises both the formal and informal segments. The former, which is the organized private sector, has contributed only a little proportion of the housing stock. Its involvement in housing provision is usually in the construction of staff quarters for their employees, and granting of housing loans. The organized private sector in most cases supplies the middle and high-income groups. The informal segment, referred to as the popular sector, has provided over $90 \%$ of houses in the country. Its activities usually mostly benefit the urban poor. The greater part of housing provided by the popular sector is non-conventional. They do not comply with established procedures, and are usually constructed outside the formal institutions, and frequently 
contravene existing legislation (CASSAD 1993; Olotuah 2005, 2015). Self-help housing constitutes a portion of this. It means houses low-income families construct with their own unpaid labour. This is however, a predominantly rural phenomenon. Families in villages organize the whole production process without paid labour. They plot land, collect materials, fabricate building components, prepare the site, and assemble the components into a house.

\section{Recommendations and Policy Implications}

\subsection{Provision of more affordable and quality housing}

There is an urgent and pressing need for the provision of more affordable and adequate dwelling units in Akure, Nigeria through public sector intervention and public, private partnership. This would raise the quality of housing and housing environment in the study area and Nigeria in general. Public sector intervention in housing requires intensification in stimulating and sensitizing further private sector participation, and in direct housing construction. Government would facilitate an enabling environment for private-sector-driven construction of houses. It would also provide funds for special low-income and rural housing. The need to undertake incisive research into the scope of the housing needs of the urban poor to unearth their qualitative, quantitative, socio-economic, cultural and psychological dimensions should be adequately addressed.

The National Housing Policy recognizes the right of every Nigerian to have access to adequate and affordable housing. As proposed by the Presidential Technical Committee on Urban Development and Housing the framework for the operation of the National Housing Policy involved restructuring of existing structures, the creation of new ones, and the promulgation of new laws. For the success of this policy, a lot of programmes have been put in place, which include:

i. The inauguration of the implementation committee on housing policy to facilitate and coordinate the implementation of the housing policy;

ii. The inauguration of the Housing Policy Council (for monitoring and evaluation of the housing policy)

The poor performance of the National Housing Policy in meeting its set goals and objectives led to a comprehensive review, which culminated in the Housing and Urban Development Policy of 2002. The major thrust of the Housing and Urban Development Policy is to meet the quantitative housing needs of Nigerians through mortgage finance. This involves the restructuring, strengthening and recapitalization of some institutions.

\subsection{Urban regeneration}

The research findings have shown that the core area of Akure, Nigeria requires upgrading in the facilities provided and the public infrastructure and services supplied to the buildings, as well as the physical environment in which the buildings are located. Some measure of urban renewal is necessary in the neighbourhood, the tools being renovation, rehabilitation and even redevelopment of some of the buildings completely. In order to ensure that buildings function adequately, public infrastructure and social services (such as electricity and water supply) must operate optimally. It behooves on government therefore to ensure that these services are rejuvenated even if it requires complete overhauling of their distribution network, which has been recognized as an inhibiting factor to their performance.

Urban regeneration needs to be addressed to improve the provision and performance of public goods and services in both rural and urban centres in Nigeria. This should be a comprehensive and integrated programme that would lead to the resolution of urban problems and bring about a lasting improvement in the economic, physical, social and environmental conditions (Tallon \& Books 2010). It would involve environmental improvement, provision of social services and infrastructure, and involvement of local communities in the regeneration process through social enterprises, nongovernmental organisations (NGOs), community-based organisations (CBOs), and resident groups (Designing buildings Ltd, 2015).

\subsection{Regenerating unfit housing}

Regeneration projects should be proposed by government based on findings from researches undertaken to establish need and expediency. The aim for the regeneration projects is to build sustainable communities through a combination of educational and socio-economic initiatives. The projects would involve rejuvenating the built environment by a mixture of demolition, construction and refurbishment of dwellings having regard to urban design guidelines. Fitness standards should be set for the buildings. 


\subsection{Implementing planning, health and safety standards}

Government through the appropriate agencies (Town and Regional Planning Offices, Ministry of Health, Capital and Urban Development Agency) should enforce planning, health and safety standards. Housing provided by the informal private sector (generally referred to as the popular sector) should be channeled through formal planning procedures to ensure compliance with building bye laws and regulations. This would reduce the incidence of poorly designed and built houses often situated in unplanned and degenerated environment.

\section{Conclusion}

This paper establishes the incidence of overwhelming housing poverty in the core area of Akure, Nigeria. The incidence of monumental housing deficiency in quantitative and qualitative measures is very glaring in the study area in particular and Nigeria in general. This is symptomatic of the severe housing malady in Nigeria which is an evidence of the debacle of public intervention in housing and grievous poverty pervading the Nigerian society. In view of the place of housing in the well-being, health and productivity of the populace it is imperative to regenerate the existing housing stock in Akure, Ondo state and in Nigeria at large. Housing regeneration programmes are thus required to rehabilitate, renovate and redevelop the existing housing stock in Nigeria. With the cooperation of governments at various levels, non-governmental organisations (NGOs), community-based organisations (CBOs) and resident-groups challenges that militate against housing regeneration could be tackled successfully.

\section{References}

Adedeji Y. M. D. and Olotuah A. O. (2012): "Accessibility of Low-Income Earners to Housing Finance in Nigeria" European Scientific Journal, $1857-7881$

Adejumo, A. A. (2008) "Some Thoughts on Affordable and Social Housing in Nigeria", Retrieved online 10 December 2008 http://www.nigeriavillagesquare.com/articles/akintokunbo-a-adejumo/some-thoughts-on-affordable-and-social-housing-innigeria.html

Ajanlekoko, J.S. (2001) "Sustainable Housing Development in Nigeria - the Financial and Infrastructural Implication" Proceedings of the International Conference on Spatial Information for Sustainable Development, Nairobi, Kenya, 2-5 October

Alagbe, O.A. (2008) "An Investigation into the Knowledge and Acceptability of Compressed Stabilized Laterite Bricks for Housing in Selected States of Southwest Nigeria, Unpublished Ph.D Thesis, Department of Architecture, Covenant University, Ota, Nigeria

Ali-Akpajiak, S.C.A. and T. Pyke, (2003) "Measuring Poverty in Nigeria" An Oxfam working papers online. Retrieved March 10,2006 http://www.oxfam.org.uk/what_we_do/resources/downloads/wp_nigeria.

Asiodu, I.P.C. (2001): "The place of housing in Nigerian economic and social development" The Quantity Surveyor, 35, 2-7

Asunmo, B and R. Iyagba (1997): "Housing Crisis in Nigeria's Urban Centres: a challenge to the construction industry and technology", The Lagos Journal of Environmental Studies, 1, $39-47$

Baratz, M.S and W.G, Grisby (1972) "Thoughts on Poverty and Its Elimination" Journal of Social Policy, 1 (2), 119-134

Basorun, J. O. (2003) Basic elements of Urban and Regional Planning; Akure, Nigeria: Shalom Publishers

Centre for African Settlement Studies and Development, CASSAD (1993): Impact of Structural Adjustment Programme (SAP) on Housing Investment, Environmental Quality and Urban Productivity in Nigeria, Research Report

Designing buildings Ltd (2015) "Housing contribution to regeneration" Designing buildings Wiki, retrieved 18 October 2015 http://www.designingbuildings.co.uk/wiki/Housing_contribution_to_regeneration

Diogu, J.O. (2002) "Housing the Poor in Nigeria: The Integrated Project Approach", Journal of Association of Architectural Educators in Nigeria (AARCHES J), 2(1) 1-6

Federal Republic of Nigeria FGN (2004) National Housing Policy for Nigeria, Federal Ministry of Works and Housing, Lagos

Igwe, J. (1987): "The Urban Poor in Nigeria: Some aspects of their residential circumstances" In Makinwa, P.K and Ozo O. A. (Eds.) The Urban Poor in Nigeria, Evans Brothers (Nig) Publishers Ltd. Ibadan, Nigeria, 271 - 280

Isimi, B. (2005) "The Role of The Private Sector in Housing Delivery in Nigeria", Journal of the Nigerian Institute of Architects, 4(4) 6-8

Lewin, A.C (1981): Housing Co-operatives in Developing Countries, JohnWiley and Sons, New York

Mabogunje, A. L. (1975) "Prolegomenon to Urban Poverty in Nigeria" Poverty in Nigeria, Proceedings of the 1975 Annual Conference of the Nigerian Economic Society, Ibadan, 69-91

Mabogunje, A.L.; Hardoy J. E. and Mistra P. R. (1978) Shelter Provision in Developing Countries; Surrey: The Gresham Press

Makinwa-Adebusoye, P.K. (1988) "Upgrading and Urban Squatter Settlement in Nigeria: the experiment in Olaleye-Iponri" In Rondinelli, D. A. and Cheema, S. (Eds.) Urban Services in Developing Countries, 175-194

Nwaka, G.I. (2006) "The Urban Poor, the Informal City and Environmental Health Policy in Nigeria" In Proceedings of the $12^{\text {th }}$ International Interdisciplinary Conference on the Environment in Kona, Hawaii, 22 -24 June

Ogunpola, A. and O. Ojo (1975) "Housing as an Indicator of Urban Poverty -The Case of Metropolitan Lagos" In Poverty in Nigeria ${ }_{1}$ Proceedings of the Conference of Nigerian Economic Society, University of Ibadan, Nigeria, 111- 124 
Okedele, O.S., Adebayo, A, K, Iweka, A. C. O. and Uduma-Olugu, N. (2009) "Infrastructural Development in Urban Cities: An Evaluation of Housing Delivery and Housing Adequacy in Lagos", Compilation of Seminar Papers, Architecture and the Nigerian Development Agenda II, Architects Colloquium, 24 - 26 March, Shehu Musa Yar'Adua Centre, Abuja, 1-16

Okupe, L. (2002) "The Role of the Private Sector in Housing Delivery in Nigeria" Shelter Watch, 4 - 11

Olanrewaju, D.O. (2001) "Urban Infrastructure A critique of Urban Renewal Process in ljora Badia" Habitat International 20: 517-530

Olotuah, A. O. (1997): "The House: Accessibility and Development - A Critical Evaluation of the Nigerian Situation" In Bayo Amole (Ed.) The House in Nigeria, Proceedings of the National Symposium, Obafemi Awolowo University lle - Ife, Nigeria, 23 - 24 July, 312 $-317$

Olotuah, A.O. (2001): "Housing Delivery and Financial Intermediation: An Appraisal of the Roles and Performances of Mortgage Institutions in Nigeria" The Quantity Surveyor, 35, 20-27

Olotuah, A.O. (2002): "An Appraisal of the Impact of Urban Services on Housing in Akure Metropolis" Journal of Science, Engineering and Technology, 9 (4) 4570-4582

Olotuah, A. O. (2005): "Sustainable Urban Housing Provision in Nigeria: A Critical Assessment of Development Options" Proceedings of the Africa Union of Architects Congress, Abuja, 23 - 28 May, 64 - 74

Olotuah, A. O. (2006): "Housing Quality in Suburban Areas (An Empirical Study of Oba-lle, Nigeria)" DIMENSI Journal of Architecture and Built Environment 34 (2) 133-137, https://doaj.org/article/43f45c9fe3334dca953a2624b31b9a08

Olotuah A.O. (2015): "Assessment of Qualitative Adequacy of Public Housing Schemes in Ado-Ekiti, Nigeria" Journal of Civil and Environmental Research, 7 (8) 58 - 62, http://www.iiste.org/Journals/index.php/CER/article/view/24640

Olotuah, A. O. and Aiyetan, A. O. (2006) "Sustainable Low-Cost Housing Provision in Nigeria: a bottom-up, participatory approach" Boyd, D (Ed.) Proceedings of 22nd Annual ARCOM Conference, 4 - 6 September, Birmingham, UK, Association of Researchers in Construction Management, 2, $633-639$

Omojinmi, I.O. (2000): SINA Technical Workshop on Housing Co-operatives, Nairobi 6 - 17 October

Omole, F. K. (2000) Urban renewal process issues and strategies, Lagos, Nigeria: Concept Books and Publication Company Nig. Ltd

Onyebueke, V.U. (2002): "Prospects of Applying Current Global Data Resources and Experiences in Urban Housing Development in Nigeria", Journal of the Tropical Environment, 2(2) 133-148

Osinubi, T.S. (2003): Urban Poverty in Nigeria: A Case study of Agege Area of Lagos State, Nigeria. Ibadan: University of Ibadan

Ozo, A.O. (1987) "Housing Conditions of the Urban Poor in Benin city" In Makinwa, P.K and O.A. Ozo (Eds.)The Urban Poor in Nigeria EvansBrothers (Nig) Publishers Ltd. Ibadan,Nigeria, 227 - 244

Sada, P. O. (1975) "Urban Poverty - The Case of Lagos, Nigeria" In P. K. Makinwa P. K. and Ozo O. A. (Eds) Poverty in Nigeria, Evans Brothers (Nig.) Publishers Ltd. Ibadan, $93-110$

Salau, A.T. (1992): "Urbanization, Housing and Social Services in Nigeria: The Challenges of Meeting Basic Needs" Cities and Development in the Third World; London: Mamzell Publishing Ltd.

Soyombo, O. (1987): "Some Issues in the Conceptualization and Theory of Urban Poverty in Nigeria" In Makinwa, P.K and O. A. Ozo (Eds.) The Urban Poor In Nigeria ${ }_{1}$ Evans Brothers (Nig) Publishers Ltd. Ibadan, Nigeria, 1 - 13

Tallon, A. and Books, D. (2010)Urban regeneration in the UK, London: Routledge

United Nations Centre for Human Settlements, UNCHS (1994) National Experiences With Shelter Delivery for the Poorest Groups, Nairobi, Kenya

United Nations (1971) "Social Programming of Housing in Urban Areas" Department of Economic and Social Affairs, New York

United Nations Centre for Human Settlements, UNCHS (2002) "Cities without Slums" World Urban Forum, Nairobi, Kenya, April 29 - May 3

Venkatarama, R. B. V. (2004): "Sustainable Building Technologies" Current Science, 87 (7) 890 - 907

Wahab, K. A., Adedokun L.A. and Onibokun A. G. (1990) "Urban Housing Conditions" In Onibokun A. G. (Ed) Urban Housing in Nigeria, Nigerian Institute of Social and Economic Research, Ibadan, 144 - 173 